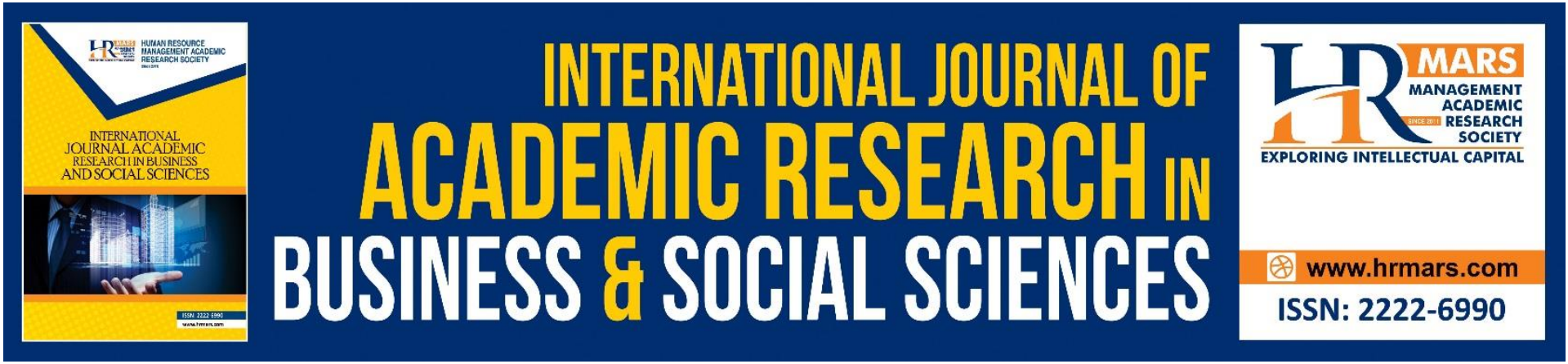

\title{
Assessing the Effectiveness of Guidance and Counselling Programme in Managing Student's Discipline in Secondary Schools in Malaysia
}

\section{Yuzalinda Mohd Yusoff, Nik Rosnah Wan Abdullah}

To Link this Article: http://dx.doi.org/10.6007/IJARBSS/v11-i4/9717

DOI:10.6007/IJARBSS/v11-i4/9717

Received: 15 February 2021, Revised: 18 March 2021, Accepted: 04 April 2021

Published Online: 19 April 2021

In-Text Citation: (Yusoff \& Abdullah, 2021)

To Cite this Article: Yusoff, Y. M., \& Abdullah, N. R. W. (2021). Assessing the Effectiveness of Guidance and Counselling Programme in Managing Student's Discipline in Secondary Schools in Malaysia. International Journal of Academic Research in Business and Social Sciences, 11(4), 709-714.

Copyright: @ 2021 The Author(s)

Published by Human Resource Management Academic Research Society (www.hrmars.com)

This article is published under the Creative Commons Attribution (CC BY 4.0) license. Anyone may reproduce, distribute, translate and create derivative works of this article (for both commercial and non-commercial purposes), subject to full attribution to the original publication and authors. The full terms of this license may be seen at: http://creativecommons.org/licences/by/4.0/legalcode

Vol. 11, No. 4, 2021, Pg. 709 - 714

Full Terms \& Conditions of access and use can be found at http://hrmars.com/index.php/pages/detail/publication-ethics 


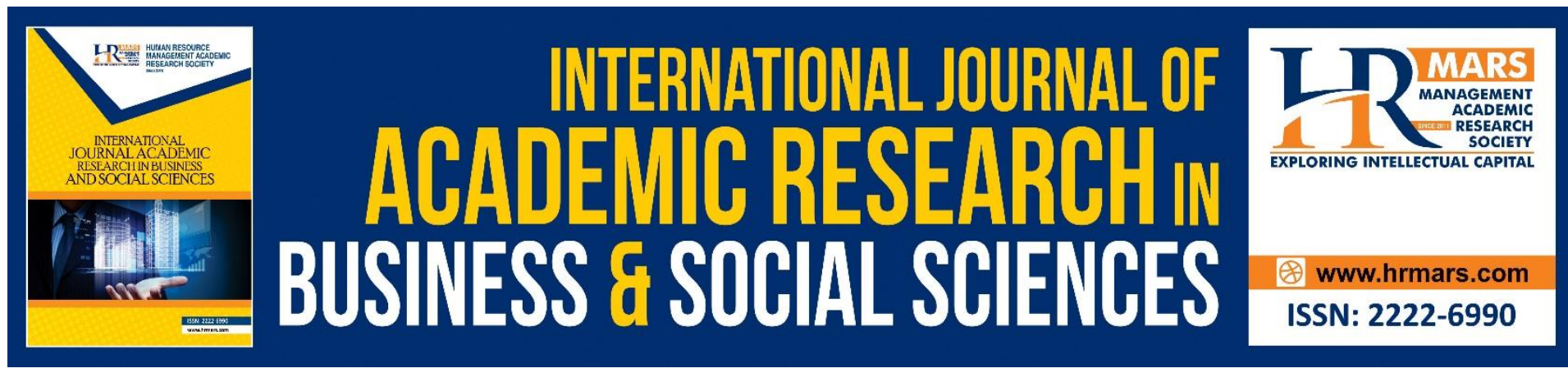

\title{
Assessing the Effectiveness of Guidance and Counselling Programme in Managing Student's Discipline in Secondary Schools in Malaysia
}

\author{
Yuzalinda Mohd Yusoff \\ Department of Graduates School of Business, Universiti Tun Abdul Razak, 195A, Jalan Tun \\ Razak, 50400, Kuala Lumpur, Malaysia
}

Nik Rosnah Wan Abdullah

Professor, Programme Director, Department of Graduates School of Government, Universiti Tun Abdul Razak, 195A, Jalan Tun Razak, 50400, Kuala Lumpur, Malaysia

Email: yuzalinda1811@ur.unirazak.edu.my

\begin{abstract}
The purpose of this study is to investigate the effectiveness of the guidance and counselling programme to manage student discipline in secondary schools in Malaysia. The study examined how secondary schools implemented the guidance and counselling strategy to maintain positive discipline. The goal of this study is to assess the performance of counsellors in addressing the disciplinary issues. It is also to explore how counsellors developed their approach in conducting their counselling with their student. This study was carried out to achieve the objectives to evaluate the effectiveness of Guidance and Counselling Services and the impact on their student. Then it is to identify the types of guidance and counselling services provided in the schools. Also, it will discuss about the challenges confront by the counsellors in the counselling duties. It adopted a qualitative approach and employed an interview design. Consequently, a qualitative approach is considered here as the best means to answer the studies research question. Qualitative approaches focus more on processes rather than on products.
\end{abstract}

Keywords: Guidance and Counselling, Disciplinary, Programme, Secondary School, Effective.

\section{Introduction}

Guidance and counseling services are important aspects of the school system. It is not just for students who are involved in disciplinary issues, but also for the positive development of individuals. It is based on the main types of mentoring and counseling programs conducted in the school. In management, there are several components that teachers need to implement before planning a thorough guidance and counseling program. School counsellors must lead the programme, make decisions, issue guidelines, integrate program management procedure and improve motivation and counseling. Then they have to evaluate the effectiveness of the 
program, identify weaknesses and problems encountered and act to address them (Amat, 2019).

\section{Background}

School counsellors in Malaysia, for instance, routinely encounter various social problems such as truancy, drug abuse, smoking, fighting, bullying, verbal and physical violence, vandalism and other destructive behavior that can impede students' academic success. This is because of the physiological and psychological changes they undergo.

The latter include questioning of family values, of self-concept, personality development, and emotional experiences. Due to this social emotional challenges that majority of students have been experiencing in schools, governments across the world saw the need for introduction of guidance and counselling services in secondary schools (Kanus, 2017).

The Education Ministry has identified a total of 402 schools nationwide as hotspots for disciplinary and drugs problems (New Straits Times, August, 2017). There are two main aims for the implementation of discipline in schools. The first aim relates to safety of the school community, i.e. students and teachers. The second is to provide a conducive learning environment that can ensure effective teaching and learning. This is because effective behavioral management either directly or indirectly paves the way for better academic success in schools (Lee, 2017).

\section{Theoretical Framework}

School discipline problems have increasingly become issues that must be addressed by all parties. If this disciplinary issue is not addressed, it may cause damage to religion, race, and nation. Prevention and treatment strategies must fit with the types of discipline problems that exist. Therefore, a counseling approach should be reviewed comprehensively to enable interventions carried out to bring positive changes to the student that have discipline problems (Jusoh et al., 2011).

For this study, as a theoretical framework is concern, this study used CTRT (Choice Theory Realty Therapy). CTRT was chosen for a detailed discussion about psychology and how counsellors can help students with problems of discipline based on their quality world, basic needs, total behaviour, and the real world. Choice Theory and Reality Therapy or CTRT was developed by William Glasser who had his doctorate clinical psychology (Glasser, 1998).

This study uses Choice Theory Reality Therapy (CTRT) because according to (Ahmad et al., 2016) it stressed that Choice Theory emphasizes that individual behavior is derived entirely from the individual's internal world (quality world). For external world (real world) gives effect to the individual after he chooses what is best for him. Internal world (quality world) consists of five basic needs that are love and belonging, power, freedom, fun and survival.

\section{CIPP Model for School Evaluation as a Framework}

CIPP model consists of three elements, namely Context, Input Process, Product approach, developed by Stufflebeam (1983). It basically provides a very systematic way of looking at many different aspects of the program development process. Although originally advocated for program development process, it can be effectively used for counselling evaluation. For 
school guidance and counselling the kind of knowledge, skills, attitudes, habits that students acquire in their educative process is the actual product.

Furthermore as stated by Sugiyo \& Muslikah (2018) the action can be made in four parts (Context-Input-Process-Product), the result of environment (context), decision on the source (input), decision on the implementation of the (process) decision on results (product) by Stufflebeam (2003), the main purpose of this assessment is to measure, translate, and validate the course of the program.

\section{Counseling Program Evaluation Cycle}

The Accountability Bridge Counselling Program Evaluation Model is a program evaluation that can be used to aid school counselors. Program evaluation is considered an applied research discipline, and is defined as a systematic process of collecting and analyzing information about efficiency, effectiveness, and impact of programs and services (Astramovich \& Coker, 2007). It is to provides a framework to be used by individual counsellors and within counselling programs and counselling agencies to plan and deliver counselling services and to assess their effectiveness and the impact of the program.

The counselling program evaluation cycle involves the planning and implementation of counselling practice and culminates with assessing the outcomes of individual and group counselling, guidance services, and counselling programs. Four stages are involved in the counselling program evaluation cycle.

\section{Figure 1. \\ Accountability Bridge Counseling Program Evaluation Model}

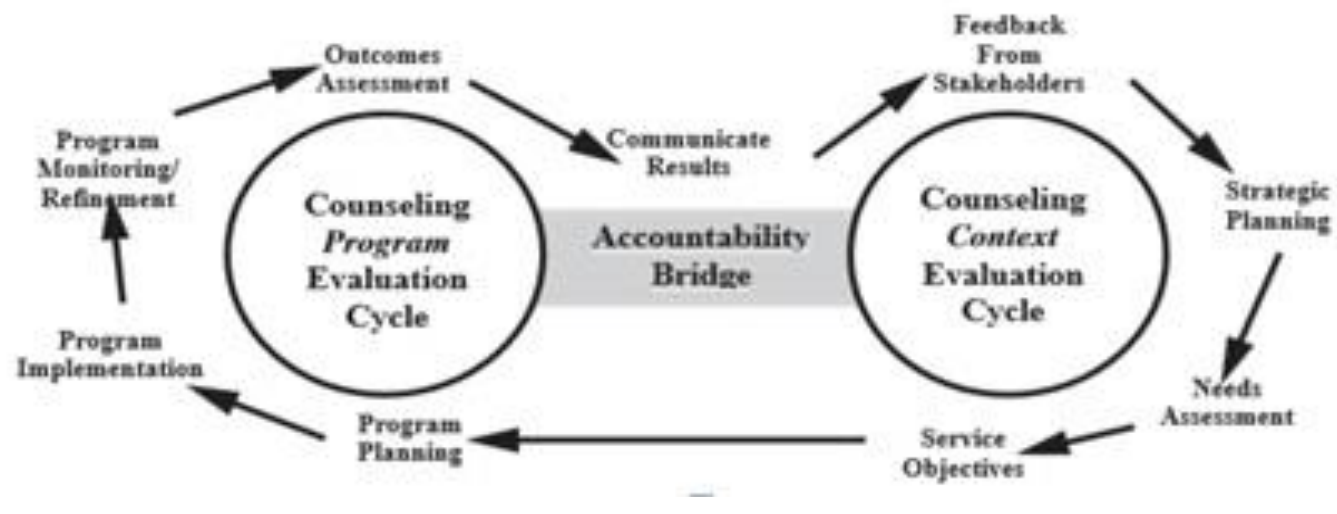

Figure 1. Accountability Bridge Counselling Program Evaluation Model

(Astramovich \& Coker, 2007).

According to figure 1, in the counselling program evaluation cycle, for this model it refers to guidance and counselling program in school. First is the program planning process, although we enter the discussion of the model at the program planning stage, information obtained from the counselling context evaluation cycle is critical in the planning process. 


\section{Research Design}

The study uses qualitative approach which typically studies people or systems by interacting with and observing the participants in their natural environment and focusing on their meanings and interpretations (Nkala, 2014).

The purpose of the research interview is to explore the views, experiences, beliefs and/or motivations of individuals on specific matters. Qualitative methods, such as interviews, are believed to provide a 'deeper' understanding of social phenomena.

Hence, the qualitative approach was pertinent to this study because the researcher will study the participants' experiences as they occurred in natural settings, that is, in Malaysian secondary schools where the guidance and counseling strategy was implemented to maintain positive discipline. This enabled the researcher to gain an insider's view of the problem under study.

\section{Conclusion}

In Malaysia, guidance and counseling services are recognized as an integral part of the total educational program and as effective means to maximize student success and student behavior. The continuous improvement and revision of school guidance and counseling services are needed in ensuring quality professional services are maintained.

School counseling services in Malaysian schools have gone through many stages and milestones, but there are still many challenges to be faced. School counselors must be accepted as essential partners in the challenge to improve educational opportunities of students in their future careers. Continued support and collaboration from all parties especially the Malaysian government is crucial to enhance the status and implementation of guidance and counseling services in Malaysian schools.

It is hoped that the findings of this study will enable students to understand, to create awareness among students about the effectiveness of the guidance and counselling programme in the management of student to avoid the disciplinary issues. In addition, this study is also hoped to be used by schools to formulate, enhance, and implement disciplinary rules, intervention programmes and safety measures to create a safe school environment.

Besides, the finding of this study is hoped to be used and guided by the Ministry of Education Malaysia to develop programmes and measures to address disciplinary issues in schools, develop training programmes on prevention among guidance and counsellors to provide guidelines common to all schools to deal with the issues.

\section{Acknowledgement}

I owe a profound gratitude to several special individuals for their support and the motivation given to me during this educational endeavor. A special thanks goes to the three-school counsellor, three staff from Education Department where the research for pilot test where this study was carried out. I truly appreciate their support, time, cooperation and courtesy to me. 
I also would like to extend my sincere thanks to Prof. Dr. Nik Rosnah Wan Abdullah (Universiti Tun Abdul Razak) Kuala Lumpur, Malaysia for her guidance and valuable tips for success, and whether you realized it or not, your advice, knowledge, encouragement, constructive feedback, and presence helped keep me grounded and motivated to succeed. I also want to thank Dr. Nurul Fadly bin Habidin (UPSI), who was a valued member of committee and who helped me to frame exactly what I was trying to get out of this research.

\section{References}

Ahmad, A., Jusoh, A. J., Shah, M. A., Arip, M., Anuar, C., Abdullah, C., ... Rohaizad, F. (2016). The Theoretical Approach in Individual Counselling: a Case Study in Malaysia DESIGN AND DEVELOPMENT OF MODULE View project NRGS on Future Teachers View project The Theoretical Approach in Individual Counselling: a Case Study in Malaysia. International Journal of Science and Engineering Investigations, 5(58), 87-90. Retrieved from www.IJSEI.com

Amat, S. (2019). Guidance and Counselling in Schools. Advances in Social Science, Education and Humanities Research, 326, 13-18. https://doi.org/10.2991/iccie-18.2019.3

Astramovich, R. L., \& Coker, J. K. (2007). Program evaluation: The accountability bridge model for counselors. Journal of Counseling and Development, 85(2), 162-172. https://doi.org/10.1002/j.1556-6678.2007.tb00459.x

Glasser, W. (1998). Choice Theory: A New Psychology of Personal Freedom. Harper Perennial, 9(1), 72-75. https://doi.org/10.1098/rsnr.2002.0171

Jusoh, A. J., Pendidikan, U., Idris, S., Mohamad, Z., Malek, A., Rahman, A., \& Jusoff, K. (2011). Construction, Reliability and Validity of Choice Theory and Reality Therapy (Ctrt) Group in. 4(23), 391-404.

Kanus, E. (2017). Influence of Guidance and Counselling Services on Students emotional adjustment in Secondary Schools in Kenya. International Journal of Education and Research, 5(5), 169-180. Retrieved from www.ijern.com

Lee. (2017). Students ' perception on disciplinary measures in public secondary schools in Akademia Baru Journal of Advanced Research in Students ' perception on disciplinary measures in public secondary schools in Kedah, Malaysia: A case study. Journal of Advanced Research in Social and Behavioural Sciences, (January 2017), 77-88.

NEW STRAITS TIMES. (2017). (n.d.). Revealed: Full list of 402 Malaysian schools with disciplinary, drug issues. Retrieved from

https://www.nst.com.my/news/nation/2017/08/268913/revealed-full-list-402-

Malaysian-schools-disciplinary-drug-issues

Nkala, P. P. (2014). An Assessment of the Guidance and Counselling Programme in Secondary Schools at Mzilikazi District in Bulawayo Metropolitan Province. IOSR Journal of Humanities and Social Science, 19(1), 81-90. https://doi.org/10.9790/0837-19138190

Stufflebeam, D. L. (2003). The CIPP Model for Evaluation. In International Handbook of Educational Evaluation (pp. 31-62). https://doi.org/10.1007/978-94-010-0309-4_4

Sugiyo, S., \& Muslikah, M. (2018). Evaluation Models of Guidance and Counseling Service Based Cipp in Senior High School. 249(Secret), 242-249. https://doi.org/10.2991/secret18.2018.41 